\title{
EFFECT OF FARMER-HERDSMEN CONFLICT ON POVERTY STATUS OF FARMING HOUSEHOLDS IN KWARA STATE, NIGERIA
}

\author{
L.O. ADEBISI ${ }^{1}$, O.A. ADEBISI ${ }^{2, *}$, A.A. OPAKUNLE ${ }^{3}$, U.G. ASOGWA ${ }^{4}$, \\ C.O. FARAYOLA ${ }^{1}$, T.O. DAODU ${ }^{1}$ \\ *E-mail: oluwaremilekunjimoh@yahoo.com
}

Received: Feb. 25, 2020. Revised: Apr, 27, 2020. Accepted: May 14, 2020. Published online: July 18, 2020

\begin{abstract}
This study examines the effect of farmer-herdsmen conflict on poverty status of crop farming households in Kwara State, Nigeria. Primary data was used for the study and a three stage sampling technique was adopted in the selection of the respondents. A structured questionnaire was used for the purpose of extracting needed information from 110 crop farming households selected for the study. The data collected were analyzed using Descriptive Statistics, Foster-Greer-Thorbecke (FGT) Index, and Tobit regression model. The result of prevalence of poverty among the farming households, who experienced conflict and those who didn't in the study area, was $19.23 \%$ and $10.34 \%$, while the intensity of poverty was 1.38 and $0.99 \%$, respectively. The severity of poverty, which measures the extent of poverty, shows poverty was more severe among
\end{abstract}

the poor who experienced conflict with a poverty index of 0.0002 than the poor who didn't experienced conflict, who had index of 0.0001 . The Tobit regression model, which measured the effects of farmer-herdsmen conflict on poverty status of the farming household, indicates that the likelihood of being poor were more with large farming households, noneducated farming household heads, small farm size, low farm income households, low off-farm income and occurrence of conflict. The study therefore recommends that governments should designate some areas for the herdsmen as grazing field and also establish grazing reserves and communities in all the states, so as to reduce farmers-herdsmen conflict.

Keywords: expenditure; pastoralist; Foster-Greer-Thorbecke (FGT); tobit regression.

\footnotetext{
${ }^{1}$ General Management Division, Agricultural Development Management Department, Agricultural and Rural Management Training Institute (ARMTI) Ilorin, Nigeria

2 Department of Agricultural Economics and Farm Management, University of Ilorin, PMB 1515, Ilorin, Nigeria

${ }^{3}$ Extension Management Division, Rural Development and Gender issue, Agricultural and Rural Management Training Institute (ARMTI) Ilorin, Nigeria

${ }^{4}$ Reseach Division, Training Technology Department, Agricultural and Rural Management Training Institute (ARMTI) Ilorin, Nigeria
} 


\section{INTRODUCTION}

Conflict has become a widespread occurrence, manifesting in different sphere of human endeavors. This is as a result of the increasing quest for secured economic sources of livelihood, which appears to be the bane for continued conflict between herdsmen and farmers in different regions. Conflicts and clashes between farmers and nomadic cattle herders have been a common feature of economic livelihood in West Africa (Tonah, 2006).

In Nigeria, there have been violent clashes between nomadic herdsmen and farmers in several places for long (Ofuoku and Isife, 2009). Prior to $20^{\text {th }}$ century, cattle's rearing was prevalent in the Guinea, Sudan and Sahel savanna of the country where crop production was carried out on small scale only during the short rainy season. This gave cattle herders access to a vast area of grass land. However, the introduction of irrigated farming in the Guinea savanna belt of Nigeria and the increased withering of pasture during dry season has made pasture less available for cattle. In search of greener pasture and fresh water for their cows, the herdsmen had to move southward to the coastal zone, where rainy season is longer and the soil retains moisture for a long period of time (Ofuoku and Isife, 2009). The migration of the herdsmen southward, where the grass is much available, make them intrude into land that has been long claimed or cultivated by settled farmers, which causes conflict (Ofem and Inyang, 2014).

The presence of the nomads and their cattle has provoked violent clashes in several communities across the country. Apart from the language and cultural barriers, which usually spots out the nomads as strangers, the audacity with which they shepherd their flocks to graze on available vegetation on their route has often attracted protests from the host communities. This scenario has given rise to an unhealthy rivalry between farmers and herdsmen leading to violence, loss of lives and property (Nweze, 2005). In some cases, a good number of community residents, mostly farmers are wiped out and those fortunate to escape have become refugees in other places. Between year 2000 till date, there have been reported cases of conflicts and confrontation between the nomads and the indigenes of the areas they migrated to with their flock in several states including: Plateau, Benue, Nassarawa, Kogi, Kastina, Kaduna, Kwara, Edo, Delta, Enugu, Abia, Taraba, Ebonyi, Ondo, Oyo, Osun and many other states. Whenever these clashes occur, the nomadic herdsmen attack and kill many villagers in the course of a contest for grazing fields and water, there are usually reprisal attacks. This scenario has, time without number, thrown up tribal, ethnic, regional, religious and political sentiments that threaten the corporate existence of both groups of people. 


\section{CONFLICT BETWEEN HERDSMENS AND FARMERS IN AGRARIAN COMMUNITIES}

Following the foregoing discussion, one can see why it is difficult for both the nomads and host communities to co-exist without problems. This is because, as the nomadic herdsmen are busy trying to protect their herds and make livelihood from their sales, the residents of host communities need to protect their farms, which these animals upon migration use as grazing land.

The resulting effect of these conflicts between them often disrupts and threatens the sustainability of pastoral farming and crop production (Moritz, 2010). These clashes reinforce circles of extreme poverty and hunger, and destroy social status, food security and affect mostly the most marginalised groups that include women and children. In the host communities, nomadic herdsmen relocate as a result of conflict and host farmers, especially women and children, who remain behind, stop going to the distant farms for fear of attack by the nomads in the bush. Such displaced farmers have become a source of liability to other farmers whom they have to beg for food for themselves and their families. This has created a vicious cycle of poverty in such communities and affected the education of children leading to obstacles in their development and mass displacement.

Therefore, the study seeks to examine the effect of farmerspastoralist conflict on poverty status of farming households in Kwara State, Nigeria. The objectives are to: describe the socio-economic characteristic of the crop farming household heads; identify the causes of farmer-herdsmen conflict, as perceived by the crop farmers; examine the poverty status of the crop farming households in the study area; examine the effect of the farmerpastoralist conflict on the poverty status of crop farming households in the study area.

\section{MATERIAL AND METHODS}

\section{Study area}

The study area was Kwara State, Nigeria. the state serves as a 'bridge' between the northern and southern parts of Nigeria and lies between latitude $7^{0} 15^{\prime} \mathrm{N}$ and longitude $6^{0} 18^{\prime} \mathrm{E}$, with a land area of about $32,500 \mathrm{sq} \mathrm{km}$. The state shares boundaries with Osun, Oyo, Ondo, Kogi, Niger and Ekiti states. It shares an international boundary with the republic of Benin. The state has a population of about 2.37 million people (National Population Council, 2006).

The state presently comprises of 16 local government areas. It is characterized by two major climatic seasons, namely the wet and dry seasons: the wet season last between April and October during which there is rain and the dry season with no rain is between November and March. The annual rainfall ranges from 1000-1500 $\mathrm{mm}$, while maximum average temperature ranges between 30 and $35^{\circ} \mathrm{C}$. The state is characterized by river Niger running through it and some other smaller rivers, like Asa. The state has sizeable expanse of arable, rich fertile soils, which is used for the cultivation of a wide variety of staples, which include maize (Kwara State Agricultural Development Project, 2007). 


\section{Data and sampling procedure}

Primary data was used for this study. The primary data which was employed for this study was collected through the use of structured questionnaire. The population for this study is made up of crop farmers. A three stage sampling technique was used in the selection of the respondents. The first stage involved purposive selection of Oke - Ero Local Government Area. The local government was selected because agriculture is the bed rock of its economy and has been a victim of Fulani-farmers' conflict for a long time, the second stage involved random selection of five villages from the local government. A number of 22 arable crop farmers were selected using snowballing techniques comprising of farming household that experienced and those who did not experience conflict. A total of 110 respondents were selected for the study.

\section{Methods of data analysis}

\section{Descriptive statistics}

Descriptive statistics, such as frequency, percentage and tabulation, was used to analyze the socio-economic characteristics of the farmers.

\section{Foster-Greer-Thorbecke (FGT) Index}

FGT poverty index was used to determine poverty levels among the respondents. It is generally given as:

$$
P_{\alpha}=1 / n \sum_{i=1}^{q}\left(z-y_{i} / z\right)^{\alpha}
$$

where: $P=$ Foster, Greer and Thorbecke index $(0 \leq P \leq 1) ; n=$ total number of respondents, i.e. farm households sampled; $q=$ number of respondents below the poverty line, i.e. poor people; $z=$ the poverty line; $y_{i}=$ per capita household expenditure of the ith respondent; $\alpha=$ on-negative poverty aversion parameter $(0,1$ or 2$)$.
The analysis of the poverty status of the households were decomposed into the three indicators, i.e. prevalence of poverty $(P 0)$, poverty depth $(P 1)$ and severity of poverty (P2). If $\alpha=0$, the index become $P O=q / n$. This gives the head count ratio or the incidence of poverty, which is the percentage of respondents in poverty, i.e. whose per capita expenditure is below the poverty line. If $\alpha=1$, it reflect both incidence and depth of poverty. If $\alpha=2$, the index measure the severity of poverty, which is the mean of square proportion of the poverty gap.

\section{Construction of the poverty line}

The poverty line was defined as the two-thirds $(2 / 3)$ of the mean value of per capita consumption expenditure in the study area. The crop farm households were categorized into poor and non-poor group using the two-third mean per capita expenditure, as the bench mark. Households whose mean consumption expenditure falls below the poverty line are regarded as being poor, while those with their expenditure above the benchmark are non-poor (Canagarajah and Thomas, 2002).

$$
\begin{aligned}
& \text { PCE }=\text { TCE } / \text { HHS } \\
& \mathrm{MPCHE}=\mathrm{THHE} / \mathrm{TNR} \\
& \mathrm{PL}=2 / 3 \text { *MPCHE }
\end{aligned}
$$

where, $\mathrm{PCE}=$ Per capita expenditure; $\mathrm{TCE}=$ Total consumption expenditure; HHS $=$ Household size; MPCHE = Mean per capita households expenditure; TNR = Total number of respondents; THHE = Total households expenditure; PL = Poverty line.

\section{Tobit Regression model}

Tobit model was developed by originally by Tobin (1958) and was used to analyze the determinants of poverty status (Adejobi, 2004; Omonona, 2000; Rahji, 1999; Oyekale, 2011).

$$
Y_{1}=\beta X_{1}+e_{1}
$$




\section{CONFLICT BETWEEN HERDSMENS AND FARMERS IN AGRARIAN COMMUNITIES}

where, $Y_{1}=$ Per capita expenditure; $B=$ Parameters estimates; $X_{i}=$ Vector of the explanatory variables; $\mathrm{X}_{1}=$ Age (years); $\mathrm{X}_{2}=$ Sex; $\mathrm{X}_{3}=$ Household size; $\mathrm{X}_{4}=$ Gender of household head; $X_{5}=$ Years of schooling; $X_{6}=$ Farm size; $X_{7}=$ Farm income; $\mathrm{X}_{8}=$ Off-farm income; $\mathrm{X}_{9}=$ Membership of farming asociation; $\mathrm{X}_{10}=$ Conflict $(1=$ experience or otherwise $)$. $\mathrm{e}_{1}=$ error term.

\section{RESULTS AND DISCUSSION}

\section{Socio-economic characteristics of farming household heads}

Table 1 revealed that $53.7 \%$ of the farming household heads fall within the age bracket of 31-50 years, with an average age of 43.48 , which shows that majority of the farmers are in their economic active age and by implication, the farming population in the study area is quite active and has the potential for increased productivity and earning. It was also revealed that households are mostly headed by males in the study area constituting about $85 \%$ of the respondents implying that women headed households constitute about $15 \%$ of the farming households population in the study area.

The result also revealed that majority $(90 \%)$ of the households head is married and the modal household size is 6-10, with a mean household size of 7.51. This supported some findings that rural dwellers usually have large families and that the large household size may provide the required labour for farming. Conversely, large household size may reduce the per capita expenditure thereby reducing economic welfare of the household, especially when the proportion of dependent is high and tends to increase poverty in the household. The distribution of farming household head also showed that more than $70 \%$ of heads had at least primary education. This implies that there are more educated household heads in the study area. Education is believed to reduce conflict and to improve household per capita income (Aikaeli, 2010). This assertion conforms to similar studies by Nnadi and Akwiwu (2008) and Muhammad-Lawal et al. (2009).

The result shown in Table 1 also reveals that the average farm size of the farming households is 2.28 hectares and this implies that farmers in the study area operate small scale farming. About $82.7 \%$ of the farmers have access to extension service and $86.4 \%$ belong to either one farmer's association or the other. Contact with extension agents was high and this implies that extension services in the area were functional and active.

The mean farming experience of the household heads is 18.09 years, while majority had experience that falls between 11-20 years; this implies that farmers in the study area are more experienced in farming.

Result also shows that about $47.3 \%$ experienced conflict in the study area, while the remaining $52.7 \%$ respondents did not. It also shows that about $65.5 \%$ of the respondents had a minimum farm income of more than 


\section{L.O. ADEBISI, O.A. ADEBISI, A.A. OPAKUNLE, U.G. ASOGWA, C.O. FARAYOLA, T.O. DAODU}

$\$ 500,000$ ( $\$ 1=\$ 0.0025941$ ) annually, non-farm income is $\$ 100,257.27$ and with a mean income was the average household expenditure is $\$ 693,636.36$. The average monthly $\$ 55,818.18$.

Table 1 - Distribution of respondents according to their socio-economic characteristics

\begin{tabular}{lll}
\hline Characteristics & Frequency & Percentage \\
\hline Age & \multicolumn{1}{l}{} \\
\hline$\leq 30$ & 15 & 13.6 \\
\hline $31-40$ & 28 & 25.5 \\
\hline $41-50$ & 31 & 28.2 \\
\hline $51-60$ & 20 & 18.2 \\
\hline$>60$ & 16 & 14.5 \\
\hline Mean age & 43.48 & \\
\hline Gender & & \\
\hline Female & 16 & 14.5 \\
\hline Male & 94 & 85.5 \\
\hline Marital status & & \\
\hline Single & 11 & 10.0 \\
\hline Married & 99 & 90.0 \\
\hline Educational level & & \\
\hline No formal & 12 & 10.9 \\
\hline Primary & 32 & 29.1 \\
\hline Secondary & 49 & 44.5 \\
\hline Tertiary & 17 & 15.5 \\
\hline Household size & & \\
\hline$<5$ & 37 & 33.6 \\
\hline $6-10$ & 53 & 48.2 \\
\hline $11-15$ & 12 & 10.9 \\
\hline$>15$ & 08 & 07.3 \\
\hline Farming experience & & \\
\hline$\leq 10$ & 19 & 17.3 \\
\hline $11-20$ & 53 & 48.2 \\
\hline $21-30$ & 23 & 20.9 \\
\hline$>30$ & 15 & 13.6 \\
\hline Mean & 18.09 & \\
\hline Farm size (hectares) & & \\
\hline$>1.0$ & 27 & 24.6 \\
\hline $1.1-2.0$ & 17 & 15.5 \\
\hline $2.1-3.0$ & 13 & 11.8 \\
\hline $3.1-4.0$ & 05 & 04.5 \\
\hline$>4.0$ & 2.28 & \\
\hline Mean & & \\
\hline & & \\
\hline & & \\
\hline & & \\
\hline
\end{tabular}




\section{CONFLICT BETWEEN HERDSMENS AND FARMERS IN AGRARIAN COMMUNITIES}

\begin{tabular}{|c|c|c|}
\hline \multicolumn{3}{|l|}{ Farms association } \\
\hline Non-member & 15 & 13.6 \\
\hline Member & 95 & 86.4 \\
\hline \multicolumn{3}{|l|}{ Extension contact } \\
\hline Access & 91 & 82.7 \\
\hline No Access & 19 & 17.3 \\
\hline \multicolumn{3}{|c|}{ Experienced conflict } \\
\hline Yes & 52 & 47.3 \\
\hline No & 58 & 52.7 \\
\hline \multicolumn{3}{|c|}{ Annual farm income (Naira) } \\
\hline$<500,000$ & 40 & 36.4 \\
\hline $501,000-700,000$ & 42 & 38.2 \\
\hline $701,000-900,000$ & 20 & 18.8 \\
\hline$>900,000$ & 8 & 7.3 \\
\hline Mean & \multicolumn{2}{|c|}{$632,636.36$} \\
\hline \multicolumn{3}{|c|}{ Monthly non-farm income (Naira) } \\
\hline$<50,000$ & 62 & 56.4 \\
\hline $51,000-100,000$ & 48 & 43.6 \\
\hline $101,000-150,000$ & 0 & 0.0 \\
\hline$>200,000$ & \multicolumn{2}{|c|}{$53,257.27$} \\
\hline \multicolumn{3}{|c|}{ Mean } \\
\hline \multicolumn{3}{|c|}{ Household monthly expenditure (Naira) } \\
\hline$<50,000$ & 65 & 59.1 \\
\hline $51,000-100,000$ & 34 & 30.9 \\
\hline $101,000-150,000$ & 11 & 10.0 \\
\hline$>200,000$ & 0 & 0.0 \\
\hline Mean & \multicolumn{2}{|c|}{$58,818.18$} \\
\hline Total & 110 & 100 \\
\hline
\end{tabular}

Source: Field Survey, 2018

Causes of conflict as perceived by the crop farmers

Table 2 shows the causes of conflict between the herdsmen and farmers, as perceived by the crop farmers. The result revealed that encroachment on farmland by pastoralist is the greatest cause of conflict, while other causes of conflict between the two groups of people include: damaging and grazing on crops, contamination of streams by cattle, indiscriminate burning of bush and sexual harassments of women.

Table 2 - Distribution of respondents based on causes of conflict

\begin{tabular}{lcc}
\hline Causes of conflict & Frequency & Percentage \\
\hline Encroachment on farmland by pastoralist & 49 & 94.2 \\
\hline Damaging and grazing on crops & 39 & 75.0 \\
\hline Contamination of streams by cattle & 30 & 57.7 \\
\hline Indiscriminate burning of bush & 29 & 55.8 \\
\hline Sexual harassments of women & 24 & 46.2 \\
\hline
\end{tabular}

$\mathrm{N}=$ multiple response Source: Field Survey, 2018 


\section{Poverty status of farming households}

Table 3 shows the result of farming households' poverty status in the study area for those who experienced conflict and those who didn't experience conflict. It shows $34.6 \%$ and $65.5 \%$ are non-poor, while $38.5 \%$ and $24.2 \%$ shows moderately poor and $14 \%$ and $6 \%$ shows the households are core poor, respectively. Also, three indicators were also used to analyze poverty: incidence of poverty $\left(P_{0}\right)$, poverty intensity $\left(P_{1}\right)$ and severity of poverty $\left(\mathrm{P}_{2}\right)$. As shown in Table 3, the prevalence of poverty among the farming households who experienced conflict and those who didn't in the study area was 0.1923 and 0.1034 , representing $19.23 \%$ and $10.34 \%$, respectively, of the farm households with consumption expenditure level below the poverty line.
The intensity of poverty measures the gap between the poor household and the poverty line (Afonja and Ogwumike, 2003). The intensity of poverty among the farming households who experienced conflict (0.0138) was higher than that of those who didn't experienced conflict in the study area (0.0240).

The implication of this is that the gap between the poor who experienced conflict and the poverty line was $1.38 \%$ apart, while the gap between the poor who didn't experienced conflict and the poverty line was $0.1034 \%$ apart. The severity of poverty, which measures the extent of poverty, shows poverty was more severe among the poor who experienced conflict with a poverty index of 0.0430 than the who didn't experienced conflict an index of 0.0010 .

Table 3 - Poverty status of farming households

\begin{tabular}{lcccc}
\hline Poverty categories & \multicolumn{2}{c}{$\begin{array}{c}\text { Farmers who } \\
\text { experienced conflict }\end{array}$} & \multicolumn{2}{c}{$\begin{array}{c}\text { Farmers who didn't } \\
\text { experienced conflict }\end{array}$} \\
\hline & Frequency & Percentage & Frequency & Percentage \\
\hline Non-poor & 18 & 34.6 & 38 & 65.5 \\
\hline Moderately poor & 20 & 38.5 & 14 & 24.2 \\
\hline Core poor & 14 & 26.9 & 06 & 10.3 \\
\hline Total & 52 & 100 & 58 & 100 \\
\hline Incidence of poverty & 0.1923 & & 0.1034 & \\
$\left(P_{0}\right)$ & 0.0138 & & 0.0430 & \\
\hline Intensity of poverty $\left(P_{1}\right)$ & 0.0010 & \\
\hline Severity of poverty $\left(P_{2}\right)$ & 0.0240 & & 0.0010 & \\
\hline
\end{tabular}

Source: Field survey, 2018

Effect of conflict on poverty status of farming households

The results in Table 4 revealed that poverty status of farming households is significantly affected by years of schooling, household size, farm size, off farm income, farm income and conflict.

The coefficient of years of schooling was negative and significant at $10 \%$, which implies that the more educated a person the less 


\section{CONFLICT BETWEEN HERDSMENS AND FARMERS IN AGRARIAN COMMUNITIES}

the likelihood of being poor. This is likely to be because such a farmer is exposed to better information and can easily adopt new methods. This is in collaboration with the result of Mugisha et al. (2004), who found that education was positively related to adoption. Being more educated gives them an advantage in understanding improved farming practices with enhance farming and increase the standard of living. Bastos et al. (2009) further corroborated that labor is by far the most important asset of the poor and increasing their education will in turn increase labor productivity and wages, which ultimately will reduce their poverty.

The coefficient of household size was also positive and significant at $10 \%$, it implies that the larger the household the likelihood of households being poor. This shows that large size households tend to reduce per capita income available and hence the average per capita expenditure reduces as household size increases. Larger household sizes can therefore be said to be poverty enhancing most, especially when they are not of working age.

The results obtained from the State further revealed that the likelihood event of being poor were more with large households. Evidence from other studies point to the same direction between poverty and household size (Okurut et al., 2002; Gang et al., 2002; Bokosi, 2006; Anyanwu, 2010; Masood and lqbal, 2010). The larger the household size the poorer the household is likely to be because more of the household members will likely be children who are unproductive and yet take a big proportion of household income in terms of school fees, medical bills, food and clothing.

The coefficient of farm size was also found to be negative and significant at $5 \%$. This shows that the lesser the farm size of a farming households the more the likelihood of being poor. The coefficient of off farm income was also negative and significant at $10 \%$, implying that a decrease in the off farm income of households increased the likelihood of the households being poor. The result also shows that the higher the off farm income, the lower the likelihood of being poor. This agrees with Azeez and Abang (2015), who further stated that off farm income can be used to augment the gains from farming activity.

The coefficient of credit access was also negative and significant at $5 \%$, implying that a decrease in the access to credit by farming households increased the likelihood of the households being poor. Access to credit by farm households has significant negative relation with poverty status and this will aid the households to escape from poverty. This is in line with the general believe that credit is an anti-poverty strategy because of the important role it plays among rural populace (Adeyeye, 2001). Credit assists the farm households in the purchase of farm inputs, such as fertilizer, herbicides, improved seeds and investment 
demand, which will ultimately increase their productivity.

Similarly, the coefficient of conflict was also found to be positive and significant at $5 \%$. This shows that the more the conflicts farming households experienced the more the likelihood of being poor.
The coefficients of determination with value 0.5964 shows that the explanatory variables explain about $59.6 \%$ of the variations in the factors influencing poverty status implying that more of the variation is explained by the model.

Table 4 - Tobit regression result of effect of conflict on poverty

\begin{tabular}{llll}
\hline Variables & Coefficient & Standard error & p>t \\
\hline Sex & 0.0261109 & 0.034282 & 0.448 \\
\hline Age & 0.0003932 & 0.001028 & 0.703 \\
\hline Years of schooling & $-0.021215^{*}$ & 0.011596 & 0.070 \\
\hline Household size & $0.018129^{*}$ & 0.010622 & 0.091 \\
\hline Membership of association & -0.004375 & 0.033973 & 0.898 \\
\hline Farm size & $-25.66169^{* *}$ & 291.9999 & 0.039 \\
\hline Off farm income & $-3.61 \mathrm{e}^{-0 / *}$ & $2.17 \mathrm{e}^{-0 /}$ & 0.099 \\
\hline Farm income & $-0.0552578^{* *}$ & 0.024319 & 0.025 \\
\hline Conflict & $0.0615147^{* *}$ & 0.026666 & 0.023 \\
\hline Constant & $0.8206496^{* * *}$ & 0.095671 & 0.000 \\
\hline Sigma & 0.1289123 & 0.009327 & \\
\hline
\end{tabular}

Source: Field survey, (2018)

${ }^{*}$ Significant at $1 \%,{ }^{* *}$ Significant at $5 \%,{ }^{* *}$ Significant at $10 \%$; Number of observation $=110$; $\operatorname{LR}_{\text {chi }}{ }^{2}(14)=144.00 ;$ Prob $>$ chi $^{2}=0.0000 ;$ Log likelihood $=-51.647179 ;$ Pseudo $R^{2}=0.5964$

\section{CONCLUSION AND RECOMMENDATION}

The study concluded that conflict between herdsmen and farmers in agrarian communities poses a serious challenge on livelihood of the hosting communities. As it has increased the incidence, intensity and severity of poverty among the farming households affected in the study area.

The study therefore recommends that governments should designate some areas for the herdsmen as grazing field and also establish grazing reserves and communities in all the states, so as to reduce farmersherdsmen conflict.

\section{REFERENCES}

Adejobi, A.O. (2004). Rural poverty, food production and demand in Kebbi State, Nigeria. Unpublished Ph.D. Thesis, Department of Agricultural Economics, University of Ibadan.

Adeyeye, V.A. (2001). Micro-credit sourced through cooperatives and rural poverty: evidence from family economic advancement programme in Osun State, Nigeria. Nigerian Institute of Social and Economic Research, NISER Monograph, Series No. 7. 


\section{CONFLICT BETWEEN HERDSMENS AND FARMERS IN AGRARIAN COMMUNITIES}

Afonja, B. \& Ogwumike, F.O. (2003). Poverty: meaning, measurement and causes. In: M.I. Obadan, A.A. Fajingbesi and E.O. Oga (Eds.). Integrated Poverty Alleviation Strategies into Plans and Programmes in Nigeria. Ibadan: Secreprints Nigeria Ltd.

Aikaeli J. (2010). Determinants of rural income in Tanzania: an empirical approach. Research Report 104, REPOA.

Anyanwu, J.C. (2010). Poverty in Nigeria: a gendered analysis. Afr. Statistical Journal, 11: 1-15.

Azeez, A. \& Abang, S.O. (2015). Analysis of poverty status of rural farm families in Akwalbom State. Global J.Agric.Sci., 14: 45-50.

Bastos, A., Casaca, S.F., Nunes, F. \& Pereirinha, J. (2009). Women and poverty: a gender-sensitive approach. J. Soc.Econ., 38(5): 764768, DOI: 10.1016/j.socec.2009.03. 008

Bokosi, F.K. (2006). Household poverty dynamics in Malawi. MPRA Paper, No.1222. Retrieved, March, 2011. Available from: http:// mpra.ub.unimuenchen.de/1222.

Canagarajah, S. \& Thomas, S. (2002). Poverty in a wealthy economy. The case of Nigeria. International Monetary Fund Working Paper, WP/02/114: 10-25.

Gang, I.N., Sen, K. \& Yun, M.-S. (2002). Poverty in rural India: ethnicity and caste. Departmental Working Paper 200634. Rutgers University, Department of Economics.

Kwara State Agricultural Development Project-KWADP (2007). Kwara State crops area and yields reports 1995-2007: KWADP Bulletin.

Masood, S.A. \& lqbal, N. (2010). Determinants of urban poverty: the case of medium sized city in Pakistan. Development Economics Working Papers 22827, East Asian Bureau of Economic Research.

Moritz, M. (2010). Understanding herderfarmer conflicts in West Africa: outline of a processual approach. Hum.Org., 69(2):138-148, DOI: 10.17730/humo.69.2.aq85k02453w8 3363

Mugisha, J., Ogwal-o, R., Ekere, W. \& Ekiyar, V. (2004). Adoption of IPM groundnut production technology in Eastern Nigeria. Afr.Crop Sci.J., 12(4): 383-391.

Muhammad-Lawal, A. Omotesho, O.A. \& Falola, A. (2009). Technical efficiency of youth participation in agriculture: a case study of the youth-in-agriculture programme in Ondo State, South Western Nigeria. NJAFE, 5(1): 20-26. University of Uyo, Akwa Ibom, Nigeria.

Nnadi, F.N. \& Akwiwu, C.D. (2008). Determinants of youths' participation in rural agriculture in Imo State, Nigeria. J.Appl.Sci., 8: 328-333, DOI: 10.3923/jas.2008.328.333

NPC (National Population Commission) (2006). Population census figures. National Population Commission, Abuja.

Nweze, N.J. (2005). Minimizing farmerherder conflicts in Fadama areas through local development plans. Implications for increased crop/livestock productivity in Nigeria. The $30^{\text {th }}$ Annual Conference of the Nigerian Society for Animal Production, University of Nigeria, Nsukka, 20-24.

Ofem, 0.0. \& Inyang, B. (2014). Livelihood and conflict dimension among crop farmers and fulani herdsmen in Yakurr region of Cross River State. Mediterr.J.Soc.Sci., MCSER Publishing, Rome-Italy, 5(8): 512-519, DOI: $10.5901 / \mathrm{mjss}$. 2014.v5n8p512

Ofuoku, A.U. \& Isife, B.I. (2009). Causes, effects and resolution of farmersnomadic cattle herders conflict in Delta state, Nigeria. Int.J.Sociol. Anthropol., 1(2): 047-054.

Okurut, F.N., Odwee, J.J.A.O. \& Adebua, A. (2002). Determinants of regional poverty in Uganda. AERC 


\section{L.O. ADEBISI, O.A. ADEBISI, A.A. OPAKUNLE, U.G. ASOGWA, C.O. FARAYOLA, T.O. DAODU}

research paper 122, Nairobi: African Economic Research Consortium.

Omonona, B.T. (2000). Poverty and Its correlates among rural farming households in Kogi State. Unpublished Ph.D. Thesis. Department of Agricultural Economics, University of Ibadan, Nigeria.

Oyekale, T.O. (2011). Impact of poverty reduction programs on multidimensional poverty in rural Nigeria. J.Sustain.Develop. in Africa, 13 (6): 1-11.
Rahji, M.A.Y. (1999). Dimensions of rural poverty and the food self-sufficiency gap in Nigeria. In: Poverty Alleviation and Food Security in Nigeria. Nigerian Association of Agricultural Economists (NAAE). Y.L. Fabiyi and E.O. Idowu (Eds.), pp. 33-37.

Tobin, J. (1958). Estimation of relationships for limited dependent variables. Econometrica, 26(1): 24-36, DOI: 10.2307/1907382

Tonah, S. (2006). Managing farmerherders' conflicts in Ghana's Volta Basin. Ibadan J.Soc.Sci., 4(1): 3345. 